\title{
REACTION OF SUGARCANE GENOTYPES TO PARASITISM OF Meloidogyne javanica AND Pratylenchus zeae ${ }^{1}$
}

\author{
CRISTIANO BELLÉ ${ }^{2 *}$, STELA MARIS KULCZYNSKI ${ }^{3}$, PAULO ROBERTO KUHN ${ }^{4}$, LORENA PASTORINI \\ DONINI $^{5}$, CESAR BAUER GOMES ${ }^{5}$
}

\begin{abstract}
The objective of this work was to evaluate the response of sugarcane genotypes to Meloidogyne javanica and Pratylenchus zeae. Sugarcane seedlings of the genotypes RB985944, RB987932, RB877935, RB855156, RB935744, RB996961, RB925345, RB935581 and RB966928 obtained from tissue cultures and maintained in pots with sterilized soil in a greenhouse were inoculated with 5,000 eggs + secondstage juveniles of $M$. javanica or 1,600 of $P$. zeae per plant, using six replicates per treatment. Tomato (Rutgers) and sorghum (BRS506) plants were used as control and proof of viability of the inoculum for the $M$. javanica and $P$. zeae, respectively. The number of root-knot in the plants inoculated with $M$. javanica, final nematode population and reproduction factor (RF) of both nematodes were evaluated at 120 days after inoculation. The averages of the different variables were compared by the Scott-Knott's clustering test at 5\%. The nematodes $M$. javanica and $P$. zeae showed $\mathrm{RF}>1.00$ in all sugarcane genotypes assessed, however, different levels of susceptibility were found. The lowest reproduction of the nematodes was found in the genotypes RB008347, RB877935, RB975944 and RB987932 (M. javanica) and RB987932 and RB966928 ( $P$. zeae).
\end{abstract}

Keywords: Saccharum spp.. Root-knot nematode. Lesion nematode. Susceptibility.

\section{REAÇÃO DE GENÓTIPOS DE CANA-DE-AÇÚCAR AO PARASITISMO DE Meloidogyne javanica E Pratylenchus zeae}

\begin{abstract}
RESUMO - Teve-se por objetivo neste trabalho avaliar a reação de genótipos de cana-de-açúcar a Meloidogyne javanica e Pratylenchus zeae. Mudas de cada material genético ('RB008347', 'RB975944', 'RB987932', 'RB877935', 'RB855156', 'RB935744', 'RB996961', 'RB925345', 'RB935581' e 'RB966928'), obtidas da cultura de tecidos e mantidas em vasos com solo esterilizado, em casa de vegetação, foram inoculados com 5.000 ovos + juvenis de segundo estádio de $M$. javanica ou 1.600 P. zeae/planta, utilizando-se seis repetições por tratamento. Para controle e a comprovação da viabilidade do inoculo, utilizaram-se plantas de tomate 'Rutgers' e sorgo 'BRS 506' para M. javanica ou P. zeae, respectivamente. Decorridos 120 dias avaliou-se o número de galhas nas plantas inoculadas com $M$. javanica; a população final de nematoide e o fator de reprodução (FR) de ambos nematoides. A seguir, as médias das diferentes variáveis foram comparadas entre si pelo teste de agrupamento de Scott-Knott a 5\%. Verificou-se que embora M. javanica e $P$. zeae tenham apresentado FR>1,00 em todos os genótipos de cana-de-açúcar testados, forma observados diferentes níveis de suscetibilidade. Desse modo, a menor reprodução do nematoide das galhas foi observada em 'RB008347', 'RB877935', 'RB975944' e 'RB987932'; e de P. zeae em 'RB987932' e 'RB966928'.
\end{abstract}

Palavras-chave: Saccharum spp.. Nematoide-das-galhas. Nematoide das lesões. Suscetibilidade.

\footnotetext{
*Corresponding author

${ }^{1}$ Received for publication in 04/15/2016; accepted in 10/17/2016.

${ }^{2}$ Department of Plant Protection, Universidade Federal de Pelotas, Capão do Leão, RS, Brazil; crbelle@gmail.com.

${ }^{3}$ Department of Agronomy, Universidade Federal de Santa Maria, Frederico Westphalen, RS, Brazil; stelamk@terra.com.br.

${ }^{4}$ Mondai Experimental Station, Empresa de Pesquisa Agropecuária e Extensão Rural de Santa Catarina, Mondaí, SC, Brazil; paulo_kn@yahoo.com.br.

${ }^{5}$ Laboratory of Plant Pathology, Embrapa Clima Temperado, Pelotas, RS, Brazil; lorenadonini@gmail.com, cesar.gomes@embrapa.br.
} 


\section{INTRODUCTION}

Sugarcane (Saccharum spp.) is one of the most socioeconomically important crops in Brazil and the world. The world's sugarcane production is

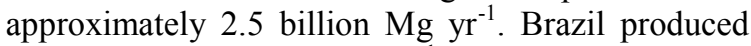
around 658.7 million $\mathrm{Mg} \mathrm{\textrm {yr } ^ { - 1 }}$ over an area of more than 8.9 million hectares, accounting for about $25 \%$ of the world's production. The sugarcane raw material is used for production of sugar, ethanol, alcoholic beverages and animal feed (CONAB, 2015).

The sugarcane area and yield is increasing in recent years; however, several factors have been limiting the production, such as the phytonematodes. Different species of these pathogens can negatively affect sugarcane crops in virtually all regions of the world where it is cultivated. According to Cadet and Spaull (2005), more than 300 phytonematode species, distributed in 48 genera, have been found in sugarcane crops, with have caused estimated average losses of $20 \%$. However, these losses may vary depending on the phytonematode species, their population levels, susceptibility of the sugarcane variety, and growing period (CHAVES et al., 2009a).

There are many species of phytonematodes that attach the roots of sugarcane plants, therefore the root-knot (Meloidogyne spp.) and root lesion (Pratylenchus spp.) nematodes are the most common pests related to damage in Brazil (DINARDO-MIRANDA et al., 2008; SEVERINO et al., 2010; BELLÉ et al., 2014). According to Severino et al. (2008) Meloidogyne javanica and M. incognita are the most common nematodes associated to sugarcane in Paraná state. In a recent survey conducted by Bellé (2014) in the northwest region of the State of Rio Grande do Sul (RS), $M$. javanica was the predominant species of root-knot nematode. Besides that these authors found Pratylenchus zeae and P. brachyurus in sugarcane crops in RS and, similar to other Brazilian regions, $P$. zeae was the predominant root-lesion specie.

The importance of root-knot nematodes in sugarcane crops can be noticed by their yield decrease due to the difficulties to control these pathogens (BARROS et al., 2005; DINARDO-MIRANDA et al., 2008). Several methods of control of nematodes have been studied, aiming to decrease phytonematode populations in sugarcane crops to levels below the economic damage threshold. Among these methods, the use of nematicides, crop rotation, soil tillage during the hottest periods of the year, resistant or tolerant varieties using and incorporation of organic matter are the most common strategies (BARROS et al., 2000). The use of genetic resistance is considered one of the most desirable control practice because it is economically feasible, accessible to producers and has no risk to human health or the environment.
However, no resistant varieties of sugarcane to root-knot and lesion nematodes are available in the Brazilian market (DIAS-ARIEIRA et al., 2010; SANTOS et al., 2012).

Considering new sugarcane genotypes have been recomended

for planting in commercial areas, especially in Rio Grande do Sul, thus, to evaluate the response of these new varieties of sugarcane to root-knot and lesion nematodes is important. Therefore, the objective of this work was to evaluate the reaction of different sugarcane genotypes to $M$. javanica and $P$. zeae.

\section{MATERIAL AND METHODS}

The experiment was conducted from December 2012 to April 2013 in a greenhouse $\left(25 \pm 3^{\circ} \mathrm{C}\right)$ at Embrapa Temperate Agriculture, Pelotas-RS. Ten adapted sugarcane genotypes (RB008347, RB975944, RB987932, RB877935, RB855156, RB935744, RB996961， RB925345, RB935581, RB966928) to the edaphoclimatic conditions of RS state and come from to the plant breeding program of the RIDESA (Rede Interuniversitária para o Desenvolvimento do Setor Sucroenergético) in partnership with Embrapa, were evaluated. Sugarcane seedlings were obtained from the genotypes through tissue culture. A completely randomized experimental design with six replicates per treatment was used.

Pure populations of $M$. javanica (Est J3) and $P$. zeae from sugarcane fields were multiplied and maintained in tomato (Solanum lycopersicum L. cv. Rutgers) and sorghum (Sorghum bicolor L. cv. BRS506) plants, respectively at greenhouse conditions $\left(25 \pm 2^{\circ} \mathrm{C}\right)$ for using as inoculum. Both nematodes were obtained from sugarcane fields in Pelotas RS, Brazil. The M. javanica population was characterized by electrophoresis technique with the isozyme esterase (CARNEIRO; ALMEIDA, 2001), and the $P$. zeae population was identified by morphological and morphometric characterization (LOOF, 1991).

Plants of sugarcane from the different genotypes were maintained in $2000 \mathrm{~cm}^{3}$ pots (one plant per pot) with vermiculite and sterilized soil (1:3) and inoculated with a suspension of 5,000 eggs + juveniles of second stage $\left(\mathrm{J}_{2}\right)$ of $M$. javanica or 1,600 P. zeae (initial population). Meloidogyne specimens were obtained through the blender grinding method with the addition of $0.5 \%$ of sodium hypochlorite followed by sieving and centrifugation with a sucrose solution (HUSSEY; BARKER, 1973; BONETTI; FERRAZ 1981) and Pratylenchus specimens were obtained through the same method without adding sodium hypochlorite (COOLEN; D'HERDE, 1972). The inoculation was carried out in three $4 \mathrm{~cm}$ deep holes around each sugarcane 
plant. The viability of the inocula was assessed by inoculate tomato Rutgers (M. javanica) and sorghum BRS506 ( $P$. zeae) plants with the same amount of inoculum at the same time as the inoculation of sugarcane seedlings.

One hundred e twenty days after inoculation, the roots of each sugarcane seedling inoculated with $M$. javanica were separated from the shoots to evaluate the number of galls. Subsequently, the eggs $+\mathbf{J}_{2}$ were extracted from the roots (final population) to quantify the nematodes and determine the nematode reproduction factor $(\mathrm{RF}=$ final population/initial population) (OOSTENBRINK, 1966). For evaluating the plants inoculated with $P$. zeae, each root system was processed for nematode extraction and counting the number of specimens to determinate the RF nematode.

The data of the different variables were submitted to analysis of variance, and the means of each treatment were compared by the Scott-Knott clustering test at 5\%, using the software SISVAR (FERREIRA, 2011). The responses of the sugarcane genotypes were classified according to the RF values of each nematode species evaluated, considering as resistant the plants whose nematode had $\mathrm{RF}<1.00$ and as susceptible those with $R F \geq 1.00$.

\section{RESULTS AND DISCUSSION}

All sugarcane genotypes evaluated were susceptible $(\mathrm{RF}>1.00)$ to $M$. javanica and $P$. zeae (Tables 1 and 2), however, the evaluated materials presented different levels of susceptibility. The mean values of RF $M$. javanica and $P$. zea in the tomato (12.75) and sorghum (15.20) plants, respectively, confirmed the viability of the inoculum used in this experiment.

Among the genotypes studied, RB008347, RB877935, RB975944 and RB987932 presented the lowest number of galls, final population and reproduction factor for $M$. javanica, thus showing a lower susceptibility. The genotypes RB996961, RB935744 and RB855156 were classified as susceptible, and the RB966928, RB925345 and RB935581 were the most susceptible genotypes to M. javanica (Table 1).

Table 1. Number of galls (NRK), final population (FP) reproduction factor (RF) of Meloidogyne javanica and susceptibility (SC) of different sugarcane genotypes to the nematode.

\begin{tabular}{crccc}
\hline Genotype & NRK & FP & RF* & SC \\
\hline RB966928 & $1,906.00 \mathrm{a}$ & $183,844.45 \mathrm{a}$ & $36.77 \mathrm{a}$ & $\mathrm{S}$ \\
RB935581 & $1,882.17 \mathrm{a}$ & $157,961.11 \mathrm{a}$ & $31.59 \mathrm{~b}$ & $\mathrm{~S}$ \\
RB925345 & $1,412.33 \mathrm{~b}$ & $125,133.33 \mathrm{~b}$ & $25.03 \mathrm{c}$ & $\mathrm{S}$ \\
RB996961 & $854.67 \mathrm{~d}$ & $105,705.56 \mathrm{~b}$ & $21.14 \mathrm{~d}$ & $\mathrm{~S}$ \\
RB935744 & $1,060.50 \mathrm{c}$ & $104,761.11 \mathrm{~b}$ & $20.95 \mathrm{~d}$ & $\mathrm{~S}$ \\
RB855156 & $1,278.00 \mathrm{~b}$ & $68,111.11 \mathrm{c}$ & $15.14 \mathrm{e}$ & $\mathrm{S}$ \\
RB877935 & $1,105.33 \mathrm{c}$ & $56,094.45 \mathrm{c}$ & $11.79 \mathrm{f}$ & $\mathrm{S}$ \\
RB987932 & $797.83 \mathrm{~d}$ & $55,461.11 \mathrm{c}$ & $11.46 \mathrm{f}$ & $\mathrm{S}$ \\
RB975944 & $525.83 \mathrm{e}$ & $47,088.89 \mathrm{~d}$ & $10.44 \mathrm{f}$ & $\mathrm{S}$ \\
RB008347 & $625.17 \mathrm{e}$ & $44,305.56 \mathrm{~d}$ & $7.93 \mathrm{f}$ & $\mathrm{S}$ \\
\hline CV & 16.42 & 16.39 & 13.92 & - \\
\hline
\end{tabular}

Averages followed by the same letter in the column do not differ by the Scott-Knott's test at $5 \%$; $\mathrm{RF}=$ final population/initial population $(\mathrm{Pi}=5,000) ; \mathrm{S}=$ Susceptible $(\mathrm{RF}>1)$.

The susceptibility of sugarcane varieties to $M$. javanica was also observed by other researchers. Dinardo-Miranda et al. (1995) assessed the response of twelve sugarcane varieties in areas naturally infested with this species and found susceptibility to this nematode in all genotypes, however, the genotypes RB735275, SP71-1632 and SP72-1861 were tolerant. Dias-Arieira et al. (2010) evaluated the response of varieties of the group $\mathrm{RB}$ to $M$. javanica, including four genotypes also evaluated in the present study (RB975942, RB855156, RB925345 and RB966928) and verified RF with values 3 to 10 times lower than those found in the present study. This result was probably due to their shorter time from inoculation to evaluation, which may have affected the number of generations of the nematode and consequently, the multiplying of the pathogen in the sugarcane plants.

The response of the genotypes to $P$. zeae showed $\mathrm{RF}>1.00$ in all genotypes, denoting the susceptibility of the tested materials to this root-lesion nematode species. However, as observed for $M$. javanica, the sugarcane genotypes presented different levels of susceptibility to $P$. zeae. The genotypes RB935744, RB008347, RB925345, RB877935 and RB975944 presented intermediate susceptibility (RF of 15.23 to 20.91), RB996961, RB855156 and RB935581 presented more 
susceptible, and RB987932 and RB966928 presented less susceptibility, as shown by their lower final population and reproduction factor nematode presented in the Table 2. Santos et al. (2012) evaluating the reaction of genotypes RB975942, RB855156, RB925345 and RB966928 to P. zeae observed RF values 3 to 10 times lower than those verified in the present study.

Table 2. Final population (FP) reproduction factor (RF) of Pratylenchus zeae and susceptibility (SC) of different sugarcane genotypes to the nematode.

\begin{tabular}{cccc}
\hline Genotype & FP & RF* & SR \\
\hline RB935581 & $42,083.33 \mathrm{a}$ & $26.31 \mathrm{a}$ & $\mathrm{S}$ \\
RB855156 & $38,227.78 \mathrm{a}$ & $25.31 \mathrm{a}$ & $\mathrm{S}$ \\
RB996961 & $36,600.00 \mathrm{a}$ & $22.87 \mathrm{a}$ & $\mathrm{S}$ \\
RB975944 & $33,461.11 \mathrm{a}$ & $20.91 \mathrm{~b}$ & $\mathrm{~S}$ \\
RB877935 & $28,250.00 \mathrm{~b}$ & $19.25 \mathrm{~b}$ & $\mathrm{~S}$ \\
RB925345 & $28,472.22 \mathrm{~b}$ & $17.80 \mathrm{~b}$ & $\mathrm{~S}$ \\
RB008347 & $24,150.00 \mathrm{~b}$ & $13.77 \mathrm{c}$ & $\mathrm{S}$ \\
RB935744 & $24,372.22 \mathrm{~b}$ & $15.23 \mathrm{c}$ & $\mathrm{S}$ \\
RB987932 & $17,088.89 \mathrm{c}$ & $10.68 \mathrm{~d}$ & $\mathrm{~S}$ \\
RB966928 & $13,655.56 \mathrm{c}$ & $8.54 \mathrm{~d}$ & $\mathrm{~S}$ \\
\hline CV (\%) & 20.37 & 15.94 & - \\
\hline
\end{tabular}

Averages followed by the same letter in the column do not differ by the Scott-Knott's test at $5 \%$; $\mathrm{RF}=$ final population/initial population $(\mathrm{Pi}=5,000) ; \mathrm{S}=$ Susceptible $(\mathrm{RF}>1)$.

According to Cadet and Spaull (2005), losses caused by $M$. javanica in production areas of sugarcane can reach $15 \mathrm{Mg} \mathrm{ha}^{-1}$. This species has been reported as one of the most frequent in Brazilian sugarcane crops (DINARDO-MIRANDA et al., 2003; SEVERINO et al., 2008; BELLÉ et al., 2014). Thus, studies on this pathogen may contribute to minimize losses in crops due to its attack.

Studies on genetic resistance are important from the point of view of phytonematode control, since responses to these pathogens are assessed through their reproduction in the hosts. Therefore, $P$. zeae multiplication in sugarcane, in general, is rapid, reaching high levels over a short period of time.

According to the $P$. zeae and $M$. javanica $\mathrm{RF}$ values presented in Tables 1 and 2, the genotype RB987932 presented the lowest levels of susceptibility. This genotype has a medium-late cycle and its main characteristic is the resistance to frost (SILVA et al., 2012), thus, it is an option for subtropical regions such as southern Brazil. Therefore is important to note that the response of the different sugarcane varieties is variable in the field and not always the largest number of nematodes means a greater reduction in the vegetative parameters of the plant. For example, Barros et al. (2005) found the highest number of nematodes (Meloidogyne + Pratylenchus) in the variety SP79-1011, however, its yield was not compromised compared with the varieties RB855156 and RB966928.

In this sense, the aggressiveness evaluation form nematode populations of the same species in distinct sugarcane genotypes are relevant for studies on genetic resistance. The susceptibility of the varieties evaluated to $M$. javanica and $P$. zeae is an important indicator of the need to adopt different control measures, since these species are widely distributed in sugarcane areas. Several management strategies are used to increase the yield of sugarcane crops (DINARDO-MIRANDA et al., 2008; CHAVES et al., 2009b; NOVARETTI; REIS, 2009), however, none have been fully effective in maintaining nematodes populations at levels below the economic damage threshold.

The results found in the present work show that all evaluated genotypes present susceptibility to $M$. javanica and $P$. zeae, however, the use of genetic materials with lower susceptibility, combined with other management strategies, may increase the viability of sugarcane crops. These measures include the incorporation of organic matter in the soil, use of antagonistic plants, crop rotation with non-host plants and reducing number of systemic nematicides. The combination of these practices can contribute to reduce phytonematode populations in sugarcane crop areas, minimizing the problems caused by them and consequently, increasing the crop yield.

\section{CONCLUSIONS}

The evaluated sugarcane genotypes present different suceptibility levels to $M$. javanica and $P$. zeae. 


\section{REFERENCES}

BARROS, A. C. B. et al. Aplicação de terbufós no controle de Meloidogyne incognita raça 1 e Pratylenchus zeae em cinco variedades de cana-de-açúcar no Nordeste. Parte 1 - Efeito na cana planta. Nematologia Brasileira, Piracicaba, v. 24, n. 1, p. 73-78, 2000 .

BARROS, A. C. B. et al. Estudo de interação variedade-nematicida em cana-de-açúcar em solo naturalmente infestado por Meloidogyne incognita, M. javanica e Pratylenchus zeae. Nematologia Brasileira, Piracicaba, v. 29, n. 1, p. 39-46, 2005.

BELLÉ, C. et al. Fitonematoides associados à cultura da cana-de-açúcar no Rio Grande do Sul, Brasil. Nematropica, Lakeland, v. 44, n. 2, p. 207-217, 2014.

BELLÉ, C. Fitonematoides na cultura da cana-de-açúcar no Rio Grande do Sul: Levantamento, caracterização e reação de genótipos a Meloidogyne javanica e Pratylenchus zeae. 2014. 107 f. Dissertação (Mestrado em Agronomia: Área de Concentração em Agricultura e Ambiente) - Universidade Federal de Santa Maria, Frederico Westphalen, 2014.

BONETTI, J. I. S.; FERRAZ, S. Modificação do método de Hussey e Barker para extração de ovos de Meloidogyne exigua de raízes de cafeeiro. Fitopatologia Brasileira, Brasília, v. 6, n. 2, p. 553, 1981.

CARNEIRO, R. M. D. G.; ALMEIDA, M. R. A. Técnica de eletroforese usada no estudo de enzimas dos nematóides de galhas para identificação de espécies. Nematologia Brasileira, Piracicaba, v. 25, n. 1 , p. 555- 560, 2001.

CADET, P.; SPAULL, V. Nematode parasites of sugarcane. In LUC, M.; SIKORA, R. A.; BRIDGE, J. (Eds.). Plant parasitic nematodes in subtropical and tropical agriculture. Wallingford: $\mathrm{CAB}$ International, 2. ed, 2005. p. 645-674.

CHAVES, A. et al. Incidência de Meloidogyne spp. e Pratylenchus sp. em cana-de-açúcar no Estado de Pernambuco, Brasil. Nematologia Brasileira, Piracicaba, v. 33, n. 4, p. 278-280, 2009a.

CHAVES, A. et al. Resistance induction to Meloidogyne incognita in sugarcane through mineral organic fertilizers. Brazilian Archives of Biology and Technology, Curitiba, v. 52, n. 6, p. 1393-1400. 2009 b.

COMPANHIA

NACIONAL

$\mathrm{DE}$
ABASTECIMENTO - CONAB. Acompanhamento de safra brasileira: cana-de-açúcar, segundo levantamento, março/2015. Disponível em: < http:// www.conab.gov.br/OlalaCMS/uploads/ arquivos/16 $02 \quad 23 \quad 17 \quad 34 \quad 53$ boletim cana portug ues_-_3o_lev_-_15-16.pdf> Acesso em: 02 jan. 2016.

COOLEN, W. A.; D'HERDE, C. J. A method for the quantitative extraction of nematodes from plant tissue. State Nematology and Entomology Research Station, Ghent, 1972. 77 p.

DIAS-ARIEIRA, C. R. et al. Reação de variedades de cana-de-açúcar aos nematoides-das-galhas. Nematologia Brasileira, Piracicaba, v. 34, n. 4, p. 198-203, 2010

DINARDO-MIRANDA, L. L. et al. Comportamento de variedades de cana-de-açúcar em relação a Meloidogyne javanica em condições de campo. Nematologia Brasileira, Piracicaba, v. 19, n. 2, p 60-66, 1995.

DINARDO-MIRANDA, L. L. et al. Danos causados por nematoide a variedades de cana-de-açúcar em cana planta. Nematologia Brasileira, Piracicaba, v. 27, n. 1, p. 69-73, 2003.

DINARDO-MIRANDA, L. L. et al. Influência da época de aplicação de nematicidas em soqueiras sobre as populações de nematoides e a produtividade da cana-de-açúcar. Bragantia, Campinas, v. 67, n. 1, p.179-190, 2008.

FERREIRA, D. F. Sisvar: a computer statistical analysis system. Ciência e Agrotecnologia, Lavras, v. 35 , n. 6 , p. 1039-1042, 2011

HUSSEY, R. S.; BARKER, K. R. A comparison of methods of collecting inocula of Meloidogyne spp., including a new technique. Plant Disease, Washington, v. 57, n. 12, p. 1025-1028, 1973.

LOOF, P. A. A. The family Pratylenchidae Thorne, 1949. In: NICKLE, W. R. (Ed.). Manual of agricultural nematology. New York: Marcel Dekker, Inc., 1991. p. 363-421.

NOVARETTI, W. R. T.; REIS, A. M. Influência do método de aplicação de nematicidas no controle de Pratylenchus zeae em soqueiras de cana-de-açúcar e definição dos níveis de dano e de controle. Nematologia Brasileira, Piracicaba, v. 33, n. 1, p. 83-89, 2009.

OOSTENBRINK, R. Major characteristics of the relation between nematodes and plants. Mededeelingen der Landbouw-Hoogeschool, Wageningen, v. 66, n. 4, p. 1-46, 1966. 
SANTOS, D. A. et al. Reaction of sugarcane genotypes to Pratylenchus brachyurus and P. zeae. International Journal of Food, Agriculture and Environment, Helsinki, v. 10, n. 1, p. 585-587, 2012.

SEVERINO, J. J. et al. Identificação de populações de Meloidogyne spp. parasitas da cana-de-açúcar na região Noroeste do Paraná pelo fenótipo da isoenzima esterase. Nematologia Brasileira, Piracicaba, v. 33, n. 3, p. 206-211, 2008.

SEVERINO, J. J. et al. Nematodes associated with sugarcane (Saccharum spp.) in sandy soils in Parana, Brazil. Nematropica, Auburn, v. 40, n. 1, p. 111-119, 2010.

SILVA, S. D. A. et al. Recomendação de variedades de cana-de-açúcar para o estado do Rio Grande do Sul. 1. ed. Pelotas: Embrapa Clima Temperado, 2012. 52 p. (Comunicado Técnico, 292). 